\title{
100. A New Agglutinable Factor in Human Blood, and Its Heredity.
}

\author{
By Shoei IseKI and Soichiro MAKINO. \\ Dept. of Legal Medicine, School of Medicine, \\ Gunma University, Maebashi, Japan. \\ (Comm. by T. Furuhata, M.J.A., Oct. 12, 1951.)
}

In serum of a mother we found a new agglutinin which is supposed to be produced through immunization by fetus, and we made a research into the frequency and heredity of the agglutinogen in human blood which corresponds to this new agglutinin.

\section{Case Report.}

Name: Atsuko Yoshida, aged 32. Married at the age of 26. Delivery three times. The first occurred at 27 , and then she was artificially delivered of a dead fetus in the 9th month of pregnancy because of eclampsia of pregnancy. The second delivery occurred at 30, normally giving birth to a boy who evidenced icterus on the 3rd day of his birth, and died on the 5th. The third delivery she had at the age of 31 . She was delivered of a girl in the 9th month of pregnancy. The child died on the $3 \mathrm{rd}$ day of birth because of extreme anemia and icterus. This is a case where the 2nd and 3rd newborn children died of erythroblastosis fetalis. We examined antibody in the mother's serum after the last delivery.

\section{Material and Method.}

The blood group of YoshidA is AMNq Rh. After absorbing anti-B agglutinin from her serum, we examined its agglutination against every group of human blood cells. For this purpose we employed the test-tube method and the hole-glass method. The antibody in this serum being perfect, the human blood, which has agglutinogen against this, causes clumping in this serum without any further treatment.

Morton and PiCKLes (I) clarified that the examination of agglutination with trypsin-treated red cells is convenient for finding out imperfect anti-Rh antibody. WIENER and KATZ (2) also reported similarly. Following Wiener and KATZ's method, we examined agglutination with trypsin-treated red cells, and observed far heavier agglutination than with non-treated red cells.

Here, however, we report the results of agglutination developed by non-treated red cells. 


\section{Experimental Results.}

As is shown in Table 1, agglutination in serum of YoshIDA does not react at $5^{\circ} \mathrm{C}$, and at $20^{\circ} \mathrm{C}$ it has agglutinin titer 4 times as high ; at $37^{\circ} \mathrm{C} \mathrm{16-32}$ times. Therefore this agglutinin belongs to the socalled "Warm Agglutinin". Further, the agglutinin titer in serum of this mother decreased in postpartum course. But when we transfused $50 \mathrm{cc}$. of $\mathrm{OMq} \mathrm{Rh}$ blood from her husband, the agglutinin titer 16 times as high against her husband's blood cells before transfusion rose to 128 times. From these experimental results agglutinin in the serum of YoshidA can be considered to be produced owing to the immunization by fetus.

Table 1.

Agglutination of serum of Yoshida at various temperature.

(Test-tube method. Determination after 1 hour.)

\begin{tabular}{|c|c|c|c|c|c|c|c|c|c|c|c|}
\hline \multicolumn{2}{|c|}{$\begin{array}{l}\text { Operating } \\
\text { Temperature }\end{array}$} & \multicolumn{4}{|c|}{$5^{\circ} \mathrm{C}$} & \multicolumn{3}{|c|}{$20^{\circ} \mathrm{C}$} & \multicolumn{3}{|c|}{$37^{\circ} \mathrm{C}$} \\
\hline \multirow{2}{*}{\multicolumn{2}{|c|}{ Blood Groups }} & \multicolumn{4}{|c|}{ Dilution of Serum } & \multicolumn{3}{|c|}{ Dilution of Serum } & \multicolumn{3}{|c|}{ Dilution of Serum } \\
\hline & & \multicolumn{4}{|c|}{$1 / 21 / 41 / 81 / 161 / 32$} & \multicolumn{3}{|c|}{$1 / 21 / 41 / 81 / 161 / 32$} & \multicolumn{3}{|c|}{$1 / 21 / 41 / 81 / 161 / 32$} \\
\hline $\mathrm{OMq}$ & $\mathrm{Rh}$ & -- & - & - & - & ++ & - & -- & $H+$ & + & + \pm \\
\hline $\mathrm{AMNq}$ & $\mathrm{Rh}$ & -- & - & - & - & ++ & - & -- & $H+$ & + & + \pm \\
\hline $\mathrm{BNq}$ & $\mathrm{Rh}$ & -- & - & - & - & + \pm & - & -- & $H+$ & + & $\pm \quad-$ \\
\hline $\mathrm{ABMNq}$ & $\mathrm{Rh}$ & -- & - & - & - & + \pm & - & -- & $H+$ & + & $\pm \quad-$ \\
\hline OMQ & $\mathrm{Rh}$ & - & - & - & - & -- & - & $-\quad-$ & - & - & $-\quad-$ \\
\hline
\end{tabular}

Provisionally we gave the name "I factor" to the agglutinogen of human blood cells which corresponds to the agglutinin found in the serum of YosHIDA, and we investigated the relation between this and groups of $\mathrm{ABO}, \mathrm{MN}, \mathrm{Q}$, and $\mathrm{Rh}$ which was reported previously.

Table 2.

Distribution of I factor in each blood group.

\begin{tabular}{|c|c|c|c|c|c|}
\hline \multirow{2}{*}{ Blood Groups } & \multicolumn{2}{|c|}{ I } & \multicolumn{2}{|c|}{ i } & \multirow{2}{*}{ Total } \\
\hline & No. & $\%$ & No. & $\%$ & \\
\hline $\begin{array}{r}\mathrm{O} \\
\mathbf{A} \\
\mathrm{B} \\
\mathrm{AB}\end{array}$ & $\begin{array}{l}53 \\
65 \\
28 \\
18\end{array}$ & $\begin{array}{l}44.9 \\
37.1 \\
38.8 \\
51.4\end{array}$ & $\begin{array}{r}65 \\
110 \\
44 \\
17\end{array}$ & $\begin{array}{l}54.1 \\
62.9 \\
61.2 \\
48.6\end{array}$ & $\begin{array}{r}118 \\
175 \\
72 \\
35\end{array}$ \\
\hline $\begin{array}{r}\mathrm{M} \\
\mathrm{N} \\
\mathrm{MN}\end{array}$ & $\begin{array}{l}30 \\
47 \\
87\end{array}$ & $\begin{array}{l}29.7 \\
52.2 \\
41.6\end{array}$ & $\begin{array}{r}71 \\
43 \\
122\end{array}$ & $\begin{array}{l}70.3 \\
47.8 \\
58.4\end{array}$ & $\begin{array}{r}101 \\
90 \\
209\end{array}$ \\
\hline $\begin{array}{l}Q \\
q\end{array}$ & $\begin{array}{r}54 \\
110\end{array}$ & $\begin{array}{l}46.5 \\
38.7\end{array}$ & $\begin{array}{r}62 \\
174\end{array}$ & $\begin{array}{l}53.5 \\
61.3\end{array}$ & $\begin{array}{l}116 \\
284\end{array}$ \\
\hline $\begin{array}{l}\mathrm{Rh} \\
\mathrm{rh}\end{array}$ & $\begin{array}{r}160 \\
4\end{array}$ & $\begin{array}{l}41.4 \\
28.5\end{array}$ & $\begin{array}{r}226 \\
10\end{array}$ & $\begin{array}{l}58.6 \\
71.5\end{array}$ & $\begin{array}{r}386 \\
14\end{array}$ \\
\hline Total & 164 & 41.0 & 236 & 59.0 & 400 \\
\hline
\end{tabular}


The results are as shown in Table 2 , from which we can see that the frequencies of I-positive and I-negative have no connection with other blood groups. The result of investigation with 400 cases showed that the frequency of I-positive was $41 \%$, I-negative $59 \%$.

Table 3.

Heredity of I Factor.

\begin{tabular}{|c|c|cc|cc|}
\hline \multirow{2}{*}{$\begin{array}{c}\text { Combination of } \\
\text { Parents }\end{array}$} & \multirow{2}{*}{$\begin{array}{c}\text { No. of } \\
\text { Families }\end{array}$} & \multicolumn{3}{|c|}{ Children } \\
\cline { 3 - 7 } & & No. & $\%$ & No. & i \\
\hline I $\times \mathrm{I}$ & 19 & 32 & 82.05 & 7 & 17.95 \\
$\mathrm{I} \times \mathrm{I}$ & 41 & 59 & 63.44 & 34 & 36.56 \\
$\mathrm{i} \times \mathrm{i}$ & 40 & 0 & 0 & 68 & 100.0 \\
\hline Total & 100 & 91 & 45.5 & 109 & 54.5 \\
\hline
\end{tabular}

The result of the examination on heredity of the I factor is as shown in Table 3.

From 19 families, in which both parents have I-factor, came 32 children with I-positive and 7 with I-negative. From 41 families, in each of which one of the parents has I-factor, came 59 children with I-positive and 34 with I-negative. From 40 families, in which neither of the parents have I factor, were born 68 children exclusively with I-negative. From these results of heredity we consider that the gene of I-positive is simple dominant against that of I-negative.

\section{Discussion.}

Antibody in serum of YoshIDA, which was reported here, decreased its agglutinin titer in postpartum course. It reacts more actively, and agglutinates her husband's blood cells more strongly in high temperature than in the low. And this antibody is supposed to be the cause of erythroblastosis fetalis which developed in her newborn children. From this view point we can consider that a new agglutinin found in serum of YoshidA was produced because the body of the mother was immunized by fetus.

Here the relationship between I factor and $\mathrm{Kh}$ factor becomes an important problem. But as is seen from the frequency of I factor and its relation to $\mathrm{Rh}$ blood type shown in Table 2 , it seems to have no direct connection with the $\mathrm{Rh}$ factor $(3,4)$ reported previously. Namely the antibody in the serum of Yoshida is not of the so-called anti-Rh $\mathrm{R}_{0}$ (D) serum. But, later, reports came from America and England of the discovery of anti- $\mathrm{Rh}^{\prime}(\mathrm{C})$, anti-Rh" $(\mathrm{E})$ antibodies in 
sera of mother who delivered erythroblastotic infants. What relation may exist between these and anti-I antibody remained a problem to be studied later.

\section{Summary.}

In serum of a mother who gave birth to erythroblastotic infants we found a new agglutinin which is different from antibody in anti- $\mathrm{Rh}_{1}(\mathrm{D})$ serum known before. But it is necessary to make comparative studies into the relation between this new agglutinin and anti-Rh' $(\mathrm{C})$, and anti-Rh" $(\mathrm{E})$ sera to be employed to determine Rh subtypes. Here we gave the provisional name of "Anti-I-Serum" to that containing this new agglutinin, and examined among Japanese the distribution of I factor which corresponds to this, finding that its frequency is about $41 \% ;$. And the research into the heredity of I factor showed that the gene of I-positive is inherited dominant against that of I-negative.

\section{References.}

1) Morton, J. A. and Pickles, M. M.: Use of trypsin in the detection of incomplete anti-Rh antibodies. Nature (Lond.), 159: 779-780, 1947.

2) Wiener, A. S. and KATz, L.: Studies on the use of enzyme-treated red cells in tests for Rh sensitization. Journ. of Immunology, $66(\mathbf{1})$ : 51-66, 1951.

3) LANDSteiner, K. and Wiener, A. S.: An agglutinable factor in human blood recognized by immune sera for rhesus blood. Proc. Soc. Exp. Biol. and Med., 43: 223-, 1940.

4) LANDsteiner, K. and Wiener, A. S.: Studies on an agglutinogen $(\mathrm{Rh})$ in human blood reacting with Anti-Rhesus sera and with human isoantibodies. J. of Exp. Med., 74 (4): 309-320, 1941. 